\title{
Pemberdayaan Masyarakat dengan Aktivitas Leisure
}

\author{
Endang Sri Wahyuni $^{*}$, Roh Hastuti Prasetyaningsih ${ }^{2}$ \\ 1,2 Jurusan Okupasi Terapi, Poltekkes Kemenkes Surakarta \\ *Email: endangsriwahyuni84@gmail.com
}

\begin{abstract}
Background: The temporary suspension of Posyandu Elderly activities has resulted in a decline in the role and function of health cadres in monitoring the health of the elderly. This is also accompanied by a decrease in the health condition of the elderly because they cannot carry out social leisure activities, which are generally carried out in the Elderly Posyandu activity forum. The purpose of this community service activity is so that cadres can optimize their role and function in monitoring the health of the elderly during a pandemic. The health of the elderly is maintained through the leisure activity program provided. Meanwhile, the elderly who are affected by Covid-19can still be guaranteed their basic needs through the distribution of existing assistance. Methods: For cadres are given counseling and training on the role of health cadres during a pandemic. Elderly people are given leisure activity programs carried out both individually and in small groups, facilitating leisure activities, counseling on preventing the spread of Covid-19, and distributing basic needs assistance for elderly people affected by Covid-19. Results: Kader has demonstrated its performance in monitoring the health of the elderly and helping facilitate elderly leisure activities. Elderly people can do leisure activities during the pandemic so they don't feel lonely anymore, feel happy because they can meet other elderly people of their age, don't feel overly afraid, and can participate in social activities to support the basic needs of elderly people affected by Covid-19. The awareness of the elderly in applying the new health norms has also increased. Conclusion: Of community empowerment with leisure activities during the pandemic can be realized thanks to cross-sectoral cooperation. This activity requires a follow-up in the form of evaluation and monitoring of existing programs.
\end{abstract}

Keywords: elderly, pandemic, leisure

\section{PENDAHULUAN}

WHO pada 30 Januari 2020 telah menyatakan Coronavirus Disease 2019 (Covid-19) sebagai kondisi darurat pada kesehatan masyarakat dan menjadi pusat perhatian dunia secara internasional (Dong et al., 2020). Kejadian tersebut bermula pada bulan Desember 2019 di Wuhan, Tiongkok ditemukan virus yang diduga sebagai akibat paparan dari pasar grosir makanan laut Huanan yang menjual berbagai macam spesies hewan hidup. Penyakit ini menyebar dengan pesat dan cepat ke kota lain di China (Yuliana 2020; Dong et al. 2020). Hal ini ditandai dengan laporan ditemukannya 44 kasus dalam kurun waktu 31 Desemeber 2019 - 3 Januari 2020 (Susilo et al., 2020).

Berdasarkan data (WHO, 2020) jumlah total kasus Covid-19 yang terkonfirmasi dari 235 negara di dunia mencapai 36.002.827 dengan jumlah kematian sebanyak 1.049.810 kasus. Data kasus di Indonesia mencapai 315.714 kejadian dengan angka kematian 11.472 kasus. Data mortalitas akibat Covid-19 di Indonesia pada rentang usia 45-54 tahun sebanyak 8\%, 55-64 tahun 14\%, dan lebih dari 65 tahun 22\%. Kondisi ini disebabkan karena kondisi lanjut usia (lansia) secara umum memiliki berbagai komorbiditas, sebagai contohnya: penyakit kardiovaskular, diabetes melitus/kencing manis, penyakit pernapasan kronik, hipertensi dan lain-lain (Kementerian Kesehatan RI, 2020). Berdasarkan data BPS tahun 2019 menunjukkan 
bahwa persentase jumlah lansia di Indonesia mencapai 9,6\% jika ditilik dari total penduduk yang ada (sekitar 25,64 juta orang). Menurut Hakim (2020), apabila Covid-19 memberikan ancaman kepada $80 \%$ populasi lansia di Indonesia seperti halnya di Tiongkok dan Amerika Serikat, maka virus ini membahayakan sekitar 20 juta lansia di Indonesia.

Lanjut usia (lansia) merupakan salah satu kelompok yang rentan dan paling beresiko terhadap adanya kematian akibat Covid-19 dan pemerintah pun telah menetapkan langkah pencegahan penularan baik secara individu, keluarga, dan masyarakat. Adapun tindakan pencegahan terhadap proses penularan Covid-19 bagi lansia meliputi: tetap tinggal di rumah, melakukan kegiatan di rumah, menjaga jarak dengan orang lain, menjaga kebersihan, memakai masker, dan lain-lain (Kementerian Kesehatan RI, 2020). Hal ini menimbulkan ketidaknyaman pada lansia dan mengakibatkan adanya rasa kesepian yang berdampak terhadap masalah kesehatan fisik dan mental yang negatif (National Academies of Sciences, 2020). Disamping itu, lansia tidak lagi dapat melakukan kegiatan leisure seperti berjalan, berkebun, bersepeda, dan kegiatan yang berkaitan dengan keseharian, keluarga, dan masyarakat (World Health Organization, 2020). Leisure merupakan kegiatan yang dilakukan seseorang dalam mengisi waktu luangnya sehingga dapat merasakan kepuasan \& mengeksplorasi identitas dirinya (Iso-Ahola \& Crowley, 1991). Leisure pada lansia yang terkait dengan kegiatan sosial kemasyarakatan pada umumnya dilakukan dalam wadah kegiatan Posyandu Lansia.

Posyandu Lansia merupakan sebuah wadah yang berfungsi sebagai forum komunikasi, alih teknologi, dan pemberian pelayanan kesehatan yang dilakukan oleh dan untuk masyarakat. Posyandu lansia ini mempunyai peran dan nilai strategis bagi pengembangan sumber daya manusia khususnya lanjut usia (Kementerian Kesehatan RI, 2020). Akan tetapi, pemerintah telah menetapkan kebijakan terkait penghentian sementara kegiatan Posyandu Lansia selama pandemi dengan tujuan untuk memutus rantai penyebaran Covid-19. Adapun dampak yang muncul adalah menurunnya peran dan fungsi kader kesehatan Posyandu Lansia dan menurunnya kondisi kesehatan psikologis pada lansia. Hal ini terjadi karena kegiatan Posyandu Lansia tidak hanya menjadi sarana untuk mempertahankan kesehatan fisik atau kebugaran lansia akan tetapi juga menjadi sarana bertemu dengan teman sebaya sehingga lansia dapat saling berinteraksi. Sedangkan pandemi, membuat mereka merasa kesepian karena tidak dapat berkumpul dan melakukan kegiatan yang biasa dilakukan. Lansia juga mengalami keterbatasan informasi tentang Covid-19, hal ini dapat diketahui dari kurangnya kesadaran lansia untuk melindungi diri sendiri. Sebagai contohnya, lansia yang merasa bosan di rumah mulai keluar rumah dan masih banyak lansia yang enggan menggunakan masker ketika melakukan aktivitas di luar rumah bahkan mereka tidak paham tentang fungsi menggunaan masker. Adapun dampak dari aspek ekonomi, lansia mengalami penurunan pendapatan karena tidak dapat bekerja lagi (Nugroho, 2020).

Untuk mengatasi kondisi tersebut, maka diperlukan kerjasama lintas sektor agar kondisi kesehatan lansia tetap terjaga. Kader berperan untuk memberikan informasi kepada lansia tentang perilaku hidup sehat, menjaga kesehatan, pembagian 
masker, memenuhi kebutuhan dasar lansia, dan bekerjasama dengan stakeholder dalam memantau kondisi kesehatan lansia (Kementerian Kesehatan RI, 2020). Hal tersebut sangat penting dilakukan karena kondisi kesehatan lansia sangat berpengaruh terhadap kualitas hidup lansia. Upaya promotif dan preventif merupakan strategi yang dapat dilakukan terapi okupasi untuk mempertahankan kondisi kesehatan lansia selama pandemi, yaitu dengan berkoordinasi dengan kader Posyandu Lansia dalam memfasilitasi kegiatan leisure lansia. Hal ini dilakukan karena lansia memerlukan strategi coping skills yang tepat untuk mengatasi keterbatasan dalam melaksanakan leisure-nya (Wang et al., 2020). Aktivitas leisure yang dapat dilakukan oleh lansia pada kondisi pandemi yaitu melakukan kegiataan sosial kemasyarakatan dengan pembatasan dan penerapan protokol kesehatan yang ketat.

Desa Ngesrep, sebagai salah satu desa di wilayah Boyolali, Jawa Tengah, juga memiliki jumlah lansia yang cukup besar (kurang lebih 1000 orang). Di Desa Ngesrep terdapat Posyandu Lansia, namun pada saat ini tidak semua dusun melaksanakan kegiatan tersebut. Salah satu dusun yang mulai menyelenggarakan Posyandu Lansia adalah Dusun IV. Berdasarkan data lansia di Posyandu Lansia Dusun IV, ditemukan beberapa lansia yang masih mengalami keterbatasan informasi tentang Covid-19 dan terdampak secara ekonomi. Sampai saat ini belum banyak upaya yang dapat dilakukan untuk mengatasi permasalahan lansia di Posyandu tersebut. Maka dari itu, fokus kegiatan Pengabdian Masyarakat ini dilakukan untuk meningkatkan dan memelihara kesehatan lansia di Dusun IV Desa Ngesrep, khususnya melalui pelatihan kader, edukasi new norma (norma baru) dalam kesehatan dan penyediaan bantuan kebutuhan dasar pada lansia dengan menerapkan protokol kesehatan yang ketat pada pelaksanaan kegiatannya.

\section{TINJAUAN PUSTAKA}

\subsection{Lansia}

Berdasarkan UU No. 13 tahun 1998 Pasal 1 Ayat 2 tentang Kesejahteraan Lanjut Usia menyatakan bahwa lanjut usia adalah seseorang yang telah mencapai usia 60 tahun ke atas (Indonesia, 1997). Berdasarkan definisi secara umum, seseorang dikategorikan ke dalam kelompok lanjut usia (lansia) apabila telah mencapai usia 65 tahun ke atas. Kondisi lansia bukan merupakan suatu penyakit, akan tetapi merupakan tahapan lanjut dari rangkaian proses kehidupan manusia yang ditandai dengan adanya penurunan pada fungsi dan kemampuan tubuh untuk beradaptasi terhadap tekanan dari lingkungan. Lansia merupakan keadaan manusia yang ditandai dengan adanya kegagalan seseorang untuk mempertahankan keseimbangan hidupnya terhadap kondisi stres fisiologis. Kegagalan ini berhubungan dengan adanya penurunan daya kemampuan untuk hidup dan peningkatan kepekaan secara individual (Efendi \& Makhfudli, 2009). Sehingga dapat disimpulkan bahwa lansia merupakan tahap lanjut pada proses kehidupan manusia yang ditandai dengan penurunan pada kemampuan tubuh yang terjadi pada usia 60 tahun ke atas.

Lansia dapat dikelompokkan berdasarkan pengelompokkan usia, dimana kelompok dengan rentang usia 49-59 tahun disebut usia pertengahan (middle age), 
usia 60-70 tahun disebut usia lanjut (elderly), kelompok 71-90 tahun disebut usia tua (old), dan kelompok usia 90 tahun keatas disebut usia sangat tua (very old) (Ouchi et al., 2017).

Proses menua atau disebut juga dengan aging adalah proses hilangnya kemampuan jaringan untuk memperbaiki atau mengganti dan mempertahankan fungsi normalnya yang terjadi secara perlahan-lahan, sehingga mengakibatkan adanya ketidakmampuan tubuh untuk bertahan terhadap adanya infeksi dan sekaligus memperbaiki kerusakan yang diderita. Penuaan pada lansia akan mengakibatkan kemunduran struktur dan fungsi organ baik yang terjadi secara fisik, psikis, mental dan sosial sehingga lansia akan menjadi rentan terhadap penyakit. Masalah yang sering dialami oleh lansia biasanya terdiri dari aspek biologi, kesehatan, psikis/psikologis, dan sosial (Nurfatimah et al., 2017).

Pandemi COVID-19 mengakibatkan adanya isolasi sosial (social distancing) yang berdampak pada kesehatan mental lansia sehingga dapat mempengaruhi kondisi psikologis lansia (Armitage and Nellums, 2020). Lansia juga mengalami hambatan untuk mengakses layanan dan dukungan kesehatan (Petretto and Pili, 2020). Disamping itu, isolasi sosial dalam waktu yang lama mengakibatkan individu memiliki rutinitas perilaku sedentari, seperti duduk, berbaring, bermain game, menonton televisi dalam waktu yang lama atau bahkan terus menerus menatap layar perangkat seluler. Hal ini mengakibatkan terjadinya penurunan tingkat aktivitas fisik yang pada akhirnya meningkatkan potensi risiko kondisi kesehatan kronis (CDC, 2020).

\subsection{Leisure}

Nowak and Nugter tahun 2009 mendefinisikan pemanfaatan waktu luang (leisure) sebagai kegiatan seseorang yang dilakukan ketika waktu luang. Leisure merupakan suatu kegiatan yang penting untuk dilakukan, karena selain memberikan kesempatan untuk bersosialisasi, leisure juga memberi manusia kesempatan untuk mengeksplorasi dan membentuk kepribadian dan identitas diri (Iso-Ahola \& Crowley, 1991). Sehingga dari beberapa pengertian yang telah dipaparkan leisure adalah kegiatan yang dilakukan untuk mengisi waktu luang dengan tujuan untuk mencapai kebahagiaan dan mengeksplorasi identitas diri.

Konsep leisure menurut (Adesoye and Ajibua, 2015) terdiri dari lima konsep yaitu: leisure dalam konsep waktu (leisure as time) adalah pilihan individu dalam menggunakan waktu luang untuk memenuhi minat dan kebutuhannya guna mendapatkan pengalaman memuaskan sehingga dapat mencapai kepuasan hidup; leisure dalam konsep permainan (leisure as play) memandang leisure sebagai permainan yang mana individu bebas dari kesibukan dan berkesempatan menyegarkan tubuh dan pikiran dari kesulitan hidup yang dihadapi; leisure dalam konsep aktivitas (leisure as activity) diartikan sebagai pilihan aktivitas yang dipilih secara bebas sebagai alternatif relaksasi, memperluas pengetahuan, partisipasi spontan, dan menyalurkan ide kratifnya; leisure dalam konsep pemikiran (leisure as state of mind) merupakan kegiatan individu untuk mengalihkan pikiran negatif/tekanan hidup untuk menemukan solusi efektif dalam mengatasi 
permasalahannya; dan leisure dalam konsep pekerjaan (leisure in relation to work) adalah sebuah motivasi dalam melakukan pekerjaan dan berfungsi untuk penyeimbang antara bekerja dan istirahat.

Leisure merupakan hal yang penting dan paling banyak dilakukan oleh lansia seiring dengan adanya penurunan tuntutan tanggung jawab dan kewajibannya dalam pekerjaan dan keluarga (Horgas, Wilms, and Baltes, 1998). Kegiatan lansia berpartisipasi dalam kegiatan sosial dapat meningkatkan kepuasan hidup lansia, kesejahteraan psikologis, kebahagiaan, dan fungsi fisik (Menec, 2003; Everard et al., 2000; Unger, Johnson, and Marks; 1997). Sedangkan kegiatan individual seperti membaca, dapat menghasilkan manfaat psikologis bagi lansia karena memberikan rasa keterlibatan dengan kehidupan (Menec, 2003).

Beberapa jenis aktivitas leisure yang biasa dilakukan oleh lansia menurut (Nurhidayah, 2016), meliputi aktivitas: duduk santai yang biasa dilakukan selama 15 menit; gerak badan/olah raga yang biasanya dilakukan di Posyandu Lansia; kegiatan kemasyarakatan (pengajian, PKK, dan posyandu); dan melakukan aktivitas ringan sehari-hari.

Manfaat melakukan aktivitas leisure di masa pandemi COVID-19adalah dapat meningkatkan kualitas hidup individu, khususnya dalam aspek psikologis, fisik, dan sosial (Guzel et al., 2020). Manfaat leisure pada aspek psikologis dapat memberikan rasa kepercayaan diri, kebahagiaan, dan pandangan yang lebih positif. Sedangkan dari aspek fisik, leisure dapat bermanfaat untuk manajemen stres seperti mengurangi kecemasan, pengurangan hormon stres dalam darah dan urin, serta perubahan suasana hati yang positif. Dalam aspek sosial, leisure bermanfaat untuk mengurangi rasa keterasingan sosial (Eskiler \& Ayhan, 2019).

\section{METODE}

Pengabdian kepada masyarakat dilaksanakan pada Agustus - September 2020. Adapun pesertanya adalah 5 kader posyandu dan 15 lansia di Dusun IV Desa Ngresrep Ngemplak Boyolali. Kegiatan ini dilakukan setiap 2 minggu sekali dalam kurun waktu 2 bulan.

Adapun metode yang diaplikasikan pada program kegiatan pengabdian kepada masyarakat meliputi kegiatan:

a. Penyuluhan dan pelatihan kader, sebagai sarana meningkatkan pengetahuan dan pemahaman dalam mengoptimalkan peran kader Posyandu Lansia selama pandemi. Peserta diberikan edukasi terkait dengan tugas kader dalam memonitor kesehatan lansia selama pandemi, teknik pemilihan aktivitas leisure (pengisian waktu luang) bagi lansia, dan menjelaskan tentang program "Jogo Tonggo". Hal tersebut dilakukan secara daring dengan menggunakan media leaflet yang disampaikan saat diskusi pada group Whatsapp dan pertemuan langsung dengan menerapkan protokol kesehatan yang ketat. Fasilitasi kegiatan leisure lansia, dilaksanakan dengan memberikan edukasi pencegahan penyebaran Covid-19, tata cara yang benar menggunakan masker dan cuci tangan, serta memberikan alternatif kegiatan leisure yang dapat dilakukan selama pandemi. Hal ini 
dilakukan melalui pendekatan individu dan kelompok kecil dengan tetap menerapkan strandar protokol kesehatan yang ketat.

b. Melaksanakan kegiatan pembagian leaflet, masker, dan penyaluran bantuan kebutuhan dasar pada lansia yang terdampak pandemi.

\section{HASIL}

Kegiatan pengabdian masyarakat yang sudah dilakukan ini telah berjalan dengan baik dan lancar. Disamping itu, tujuan dari kegiatan pengabdian masyarakat ini juga dapat tercapai. Dari pelatihan kepada kader kesehatan Posyandu Lansia, pelaksanaan aktivitas leisure, penyuluhan, serta penyerahan bahan dasar kebutuhan sehari-hari kepada lansia terdampak Covid-19 telah dilaksanakan sesuai perencanaan dengan memenuhi standar protokol kesehatan yang ketat. Kader telah menunjukkan peran dan kinerjanya dalam memantau kesehatan lansia dan membantu memfasilitasi kegiatan leisure lansia. Ditinjau dari segi pengetahuan lansia, berdasarkan tanya jawab yang dilakukan, lansia memiliki pengetahuan yang lebih baik mengenai cara menjaga jarak, mencuci tangan, dan penggunaan masker yang benar. Berdasarkan dari hasil wawancara, dapat diketahui bahwa para lansia tersebut dapat merasakan manfaat setelah melakukan aktivitas leisure diantaranya: tidak merasa kesepian lagi, merasa senang atau bahagia karena dapat bertemu dengan lansia yang lain, tidak merasa takut berlebihan, dan dapat berpartisipasi dalam kegiatan sosial dalam hal ini turut serta memberikan bantuan materiil dan dukungan moril serta menyalurkan bahan dasar kebutuhan hidup bagi lansia yang terdampak Covid-19.

Kesadaran lansia dalam menggunakan masker meningkat, hal tersebut dapat dilihat dari konsistensi penggunaan masker saat lansia ke luar rumah. Secara umum, para lansia tersebut memberikan respon yang positif terhadap kegiatan yang diberikan, sangat antusias terhadap program kegiatan dalam aktivitas leisure yang telah dilaksanakan. Adapun data hasil pelatihan dapat dicermati pada gambar 1. Data Perubahan Perilaku pada Pelatihan di bawah ini. 


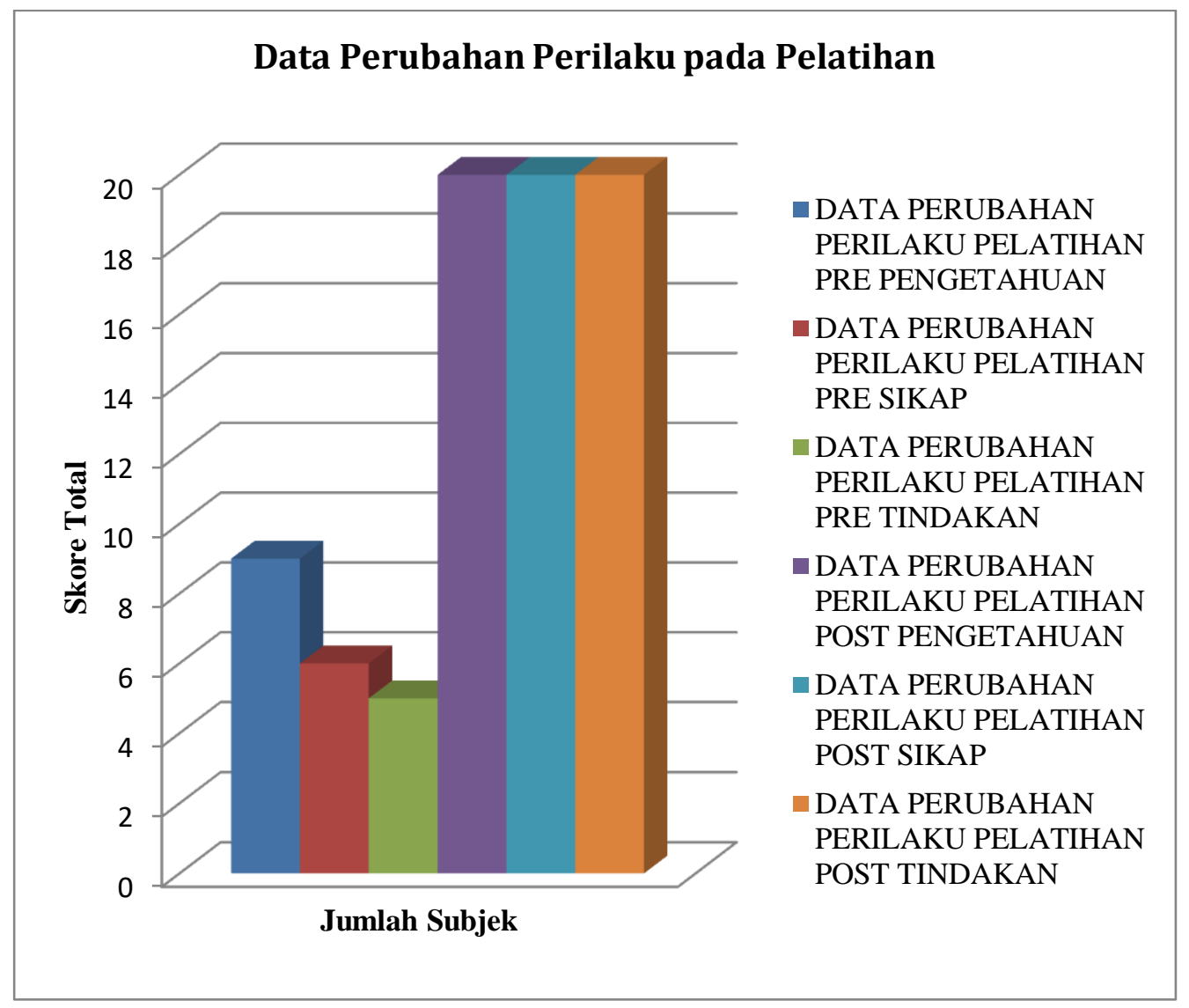

Gambar 1. Data Perubahan Perilaku pada Pelatihan

\section{PEMBAHASAN}

Kegiatan pengabdian masyarakat dilaksanakan melalui pemberdayaan masyarakat dengan aktivitas leisure sebagai sarana untuk meningkatkan fungsi dan peran kader kesehatan selama pandemi. Hal ini juga bertujuan untuk mempertahankan dan meningkatkan kondisi kesehatan psikologis lansia selama pandemi melalui aktivitas leisure. Leisure pada lansia yang terkait dengan kegiatan sosial kemasyarakatan yang pada umumnya dilakukan dalam wadah kegiatan Posyandu Lansia. Hal ini sejalan dengan Permenkes RI tahun 2017 yang menyatakan bahwa Posyandu Lansia merupakan suatu wadah dalam rangka pemberian pelayanan kepada lansia di masyarakat yang jenis pelayanannya meliputi pelayanan kesehatan, pemberian makan tambahan (PMT), kegiatan olah raga, dan kegiatan non kesehatan (kegiatan kerohanian, arisan, ekonomi produktif, berkebun, forum diskusi, dan penyaluran hobi termasuk leisure).

Lansia di Dusun IV Desa Ngresrep Ngemplak Boyolali yang mengalami isolasi sosial setelah penutupan Posyandu Lansia, kondisi ini menyebabkan banyak dari lansia tersebut yang merasakan adanya rasa tertekan, cemas, ketakutan, khawatir, dan berbagai gejala psikosomatis seperti pusing, berdebar-debar, sakit perut, dan merasa seperti sesak napas yang sebelumnya tidak pernah dialami. Lansia juga mengalami 
keterbatasan informasi tentang kondisi di lingkungan sekitarnya terutama informasi tentang Covid-19. Hal tersebut didukung oleh penelitian Nugroho (2020) yang memaparkan bahwa dengan adanya penghentian sementara kegiatan Posyandu Lansia selama pandemi berdampak terhadap penurunan kondisi kesehatan psikologis pada lansia, keterbatasan informasi tentang Covid-19, kurangnya kesadaran lansia untuk melindungi diri sendiri, dan keterbatasan ekonomi.

Untuk mengatasi kondisi tersebut, maka okupasi terapi bekerjasama dengan stakeholder Posyandu Lansia untuk memberdayakan kader dan lansia. Berdasarkan Kementerian Kesehatan RI (2020), kader berperan untuk memberikan informasi kepada lansia tentang perilaku hidup sehat, menjaga kesehatan, pembagian masker, memenuhi kebutuhan dasar lansia, dan bekerjasama dengan stakeholder dalam memantau kondisi kesehatan lansia sesuai dengan Panduan Pelayanan Kesehatan Lanjut Usia pada Era Pandemi Covid-19. Salah satu metode yang digunakan pada kegiatan pengabdian kepada masyarakat ini adalah penyuluhan dengan sistem daring/online menggunakan media leaflet. Tindakan ini merujuk pada konsep perubahan perilaku manusia yang dipaparkan oleh Amanah (2007) bahwa penyuluhan merupakan tindakan praktis tentang segala upaya yang dilakukan sebagai usaha untuk mendorong terjadinya perubahan perilaku baik pada individu, kelompok, komunitas, dan masyarakat agar mereka menjadi tahu, mau, dan mampu menyelesaikan permasalahan yang ada. Penggunaan media leaflet secara daring/online sangat efektif karena memiliki kelebihan yaitu kapasitas file gambar yang digunakan hanya kecil sehingga tidak memerlukan paket data yang banyak untuk mengunduh dan hasil unduhan dapat disebarluaskan dengan cepat serta dilihat dengan mudah dan berulang-ulang (Sabarudin et al., 2020). Fasilitasi aktivitas leisure terhadap lansia pada kondisi pandemi yaitu melakukan kegiataan sosial kemasyarakatan berupa penyuluhan norma baru kesehatan dalam kelompok kecil yang mana setiap kelompok terdiri dari 5 lansia. Disamping itu juga dengan kegiatan penyaluran dan penyerahan bantuan kebutuhan dasar hidup kepada lansia yang terdampak Covid-19. Samper et al. (2017) memaparkan bahwa dengan adanya hubungan interaksi sosial yang baik pada lansia, akan menumbuhkan perasaan memiliki suatu kelompok sehingga mereka dapat saling berbagi cerita, pengalaman, minat, perhatian, serta dapat melakukan kegiatan kreatif dan inovatif secara bersamasama. Senada dengan hasil penelitian Sagitta (2017) yang menyatakan bahwa kegiatan sosial lansia dapat berdampak terhadap penurunan tingkat kecemasan lansia karena dengan adanya aktivitas sosial, lansia dapat berbagi dengan lansia yang lain melalui aktivitas yang dilakukan secara bersama dalam kehidupan sosial kemasyarakatan. Kegiatan leisure yang diprogramkan kepada lansia berdasar pada konsep leisure as time, leisure as activity, dan leisure as state of mind. Hal ini dilaksanakan berdasarkan pada teori Adesoye \& Ajibua (2015) yang menyatakan bahwa leisure dalam konsep waktu (leisure as time) merupakan pilihan individu dalam menggunakan waktu luang untuk memenuhi minat dan kebutuhannya guna mendapatkan pengalaman memuaskan sehingga dapat mencapai kepuasan hidup. Sedangkan (leisure as activity) diartikan sebagai pilihan aktivitas yang dipilih secara bebas sebagai alternatif relaksasi, memperluas pengetahuan, partisipasi spontan, dan 
menyalurkan ide kreatifnya dan leisure dalam konsep pemikiran (leisure as state of mind) merupakan kegiatan individu untuk mengalihkan pikiran negatif/tekanan hidup untuk menemukan solusi efektif dalam mengatasi permasalahannya. Pelaksanaan leisure pada lansia di Dusun IV ini dapat berjalan dengan baik karena lansia diajarkan untuk menerapkan strategi coping skills yang tepat untuk mengatasi keterbatasan dalam melaksanakan leisure-nya (Wang et al., 2020). Aktivitas leisure sangat diperlukan bagi lansia untuk meningkatkan kualitas hidup, kepuasan hidup, dan menjaga kesehatan fisik serta mental (Ikawati, 2013).

\section{KESIMPULAN DAN SARAN}

\subsection{Kesimpulan}

Berdasarkan hasil kegiatan pengabdian masyarakat yang telah dilaksankan, maka dapat disimpulkan bahwa kader kesehatan Posyandu Lansia dapat melaksanakan peran dan fungsinya secara optimal dalam rangka memonitor kesehatan dan memfasilitasi kegiatan leisure lansia meskipun terdapat penghentian sementara kegiatan Posyandu Lansia selama pandemi. Lansia tidak lagi mengalami kesepian, merasa sendiri dan terkurung dengan adanya aktivitas leisure yang dilakukan. Pemahaman lansia tentang Covid-19menjadi lebih baik dan kesadaran lansia dalam menerapkan norma baru kehidupan terutama dalam perilaku hidup bersih dan sehat semakin meningkat. Sedangkan bagi lansia yang terdampak Covid19tidak merasa takut dan khawatir terhadap stigma yang ada di masyarakat serta terjamin kebutuhan dasar hidupnya.

\subsection{Saran}

Kegiatan pengabdian masyarakat ini memerlukan tindak lanjut diantaranya: kader dan pemangku wilayah (dusun, RT) diharapkan dapat meneruskan kegiatan ini secara rutin selama pandemi walaupun kegiatan pengabmas telah berakhir. Lansia tetap melanjutkan program pada aktivitas leisure berdasarkan copping skills yang telah diberikan dengan baik di rumah maupun pada kelompok masyarakat lansia seperti Posyandu Lansia.

\section{UCAPAN TERIMA KASIH}

Terima kasih yang tak terhingga kami haturkan kepada Satino, SKM., MSc. selaku Direktur Politeknik Kesehatan Kemenkes Surakarta. Khomarun, M.OT selaku Ketua Jurusan Okupasi Terapi Politeknik Kesehatan Kemenkes Surakarta. Yuyun Setyorini,SKp,Ns.,MKep, selaku Kepala Pusat Penelitian dan Pengabdian Masyarakat Politeknik Kesehatan Kemenkes Surakarta yang telah memberikan kesempatan dan dukungan atas penyelenggaraan kegiatan pengabdian kepada masyarakat ini sehingga kegiatan ini dapat dilaksanakan dengan baik dan lancar.

\section{DAFTAR RUJUKAN}

Adesoye, A. A., \& Ajibua, M. A. (2015). Exploring The Concept Of Leisure And Its Impact On Quality Of Life. American Journal of Social Science Research, $1(2), 77-84$. 
Amanah, S. (2007). Jurrnal Penyuluhan. 3(1), 63-67. https://repository.ipb.ac.id/jspui/bitstream/123456789/43055/1/Siti Amanah.pdf

Armitage, R., \& Nellums, L. B. (2020). COVID-19 and the consequences of isolating the elderly. The Lancet Public Health, 5(5), e256. https://doi.org/10.1016/S2468-2667(20)30061-X

Dong, Y., Dong, Y., Mo, X., Hu, Y., Qi, X., Jiang, F., Jiang, Z., Jiang, Z., Tong, S., Tong, S., \& Tong, S. (2020). Epidemiology of COVID-19 among children in China. Pediatrics, 145(6). https://doi.org/10.1542/peds.2020-0702

Eskiler, E., \& Ayhan, C. (2019). The Effect of Leisure Benefits on Leisure Satisfaction: Extreme Sports. Turkish Journal of Sport and Exercise, May, 2125. https://doi.org/10.15314/tsed.522984

Everard, K. M., Lach, H. W., Fisher, E. B., \& Baum, M. C. (2000). Relationship of activity and social support to the functional health of older adults. Journals of Gerontology - Series B Psychological Sciences and Social Sciences, 55B(4), S208-S212. https://doi.org/10.1093/geronb/55.4.S208

Güzel, P., Yıldız, K., Esentaş, M., \& Zerengök, D. (2020). " Know-How " to Spend Time in Home Isolation during COVID-19; Restrictions and Recreational Activities "Know-How " to Spend Time in Home Isolation during COVID-19; Restrictions and Recreational Activities. May. https://doi.org/10.17220/ijpes.2020.02.011

Hakim, L. N. (2020). Pelindungan Lanjut Usia Pada Masa Pandemi Covid-19. Perlindungan Lanjut Usia Pada Masa Pandemi Covid-19, XII, 13-18. http://berkas.dpr.go.id/puslit/files/info_singkat/Info Singkat-XII-10-II-P3DIMei-2020-243.pdf

Horgas, A. L., Wilms, H. U., \& Baltes, M. M. (1998). Daily life in very old age: Everyday activities as expression of successful living. Gerontologist, 38(5), 556-568. https://doi.org/10.1093/geront/38.5.556

Ikawati. (2013). Pengaruh Pengisian Waktu Luang terhadap Kebahagiaan Lanjut Usia. 12(1), 27-44.

Indonesia, R. (1997). Undang-Undang Republik Indonesia No 13 Tahun 1998 Tentang Kesejahteraan Lanjut Usia. http://www.bphn.go.id/data/documents/98uu013.pdf 
Iso-Ahola, S. E., \& Crowley, E. D. (1991). Adolescent Substance Abuse and Leisure Boredom. Journal of Leisure Research, 23(3), 260-271. https://doi.org/10.1080/00222216.1991.11969857

Kementerian Kesehatan RI. (2020). Panduan Pelayanan Kesehatan Lanjut Usia pada Era Pandemi Covid-19. In Kementerian Kesehatan RI. Direktorat Jenderal Kesehatan Masyarakat (Issue Mei). Kementerian Kesehatan RI.

Menec, V. H. (2003). and Successful Aging: A 6-Year Longitudinal Study. Social Sciences, 58(2), 74-82.

Nowak, M. J., \& Nugter, M. A. (2009). ['I'll serve my time...' II. A replication study of recidivism in patients with a one-year hospital order]. Tijdschrift Voor Psychiatrie, $71(7)$ 725-732. https://doi.org/10.1097/PSY.0b013e3181ad7978.Association

Nugroho, H. S. 2020. N. P. L. S. P. C.-19. Y. : S. (2020). Nasib Posyandu Lansia Saat Pandemi Covid-19. Kedaulatan Rakyat, 7. https://surveymeter.org/en/node/571

Nurhidayah, N. (2016). Pemanfaatan Waktu Luang (Leisure) Dalam Aktivitas Kehidupan Sehari-Hari Lansia Di Posyandu Kedung Gobyak Desa Sobokerto Kecamatan Ngemplak Boyolali. Jurnal Keterapian Fisik, 1(2), 95-103. https://doi.org/10.37341/jkf.v1i2.89

Ouchi, Y., Rakugi, H., Arai, H., Akishita, M., Ito, H., Toba, K., \& Kai, I. (2017). Redefining the elderly as aged 75 years and older: Proposal from the Joint Committee of Japan Gerontological Society and the Japan Geriatrics Society. Geriatrics and Gerontology International, 17(7), 1045-1047. https://doi.org/10.1111/ggi.13118

Permenkes RI. (2017). Penyelenggaraan Pelayanan Kesehatan Lanjut Usia Di Pusat Kesehatan Masyarakat. In Kementrian Kesehatan Indonesia. Kementerian Kesehatan RI. http://kesga.kemkes.go.id/images/pedoman/Permenkes 672015 Yankes Lansia Puskesmas.pdf

Petretto, D. R., \& Pili, R. (2020). Ageing and COVID-19: What is the role for elderly people? Geriatrics (Switzerland), 5(2), 1-4. https://doi.org/10.3390/Geriatrics5020025

Sabarudin, Mahmudah, R., Ruslin, Aba, L., Nggawu, L. O., Syahbudin, Nirmala, F., Saputri, A. I., \& Hasyim, M. S. (2020). Efektivitas Pemberian Edukasi secara Online melalui Media Video dan Leaflet terhadap Tingkat Pengetahuan Pencegahan Covid-19 di Kota Baubau. Jurnal Farmasi Galenika (Galenika 
Journal of Pharmacy) (e-Journal), 6(2), 309-318. https://doi.org/10.22487/j24428744.2020.v6.i2.15253

Sagitta, A. . (2017). Hubungan Aktivitas Sosial Dengan Kualitas Hidup Lansia Di Padukuhan Karang Tengah Nogotirto Gamping Sleman Yogyakarta. Fakultas Ilmu Kesehatan Universitas 'Aisyiyah Yogyakarta. http://digilib.unisayogya.ac.id/2511/

Samper, T. P., Pinontoan, O. R., \& Katuuk, M. E. (2017). Hubungan Interaksi Sosial Dengan Kualitas Hidup Lansia Di Bplu Senja Cerah Provinsi Sulawesi Utara Trisnawati. E-Journal Keperawatan, 5(1), 1-9.

Susilo, A., Rumende, C. M., Pitoyo, C. W., Santoso, W. D., Yulianti, M., Herikurniawan, H., Sinto, R., Singh, G., Nainggolan, L., Nelwan, E. J., Chen, L. K., Widhani, A., Wijaya, E., Wicaksana, B., Maksum, M., Annisa, F., Jasirwan, C. O. M., \& Yunihastuti, E. (2020). Coronavirus Disease 2019: Tinjauan Literatur Terkini. Jurnal Penyakit Dalam Indonesia, 7(1), 45. https://doi.org/10.7454/jpdi.v7i1.415

Unger, J. B., Johnson, C. A., \& Marks, G. (1997). Functional decline in the elderly: Evidence for direct and stress- buffering protective effects of social interactions and physical activity. Annals of Behavioral Medicine, 19(2), 152-160. https://doi.org/10.1007/BF02883332

Wang, H., Xia, Q., Xiong, Z., Li, Z., Xiang, W., Yuan, Y., Liu, Y., \& Li, Z. (2020). The psychological distress and coping styles in the early stages of the 2019 coronavirus disease (COVID-19) epidemic in the general mainland Chinese population: A web-based survey. PLoS ONE, 15(5), 1-10. https://doi.org/10.1371/journal.pone.0233410

WHO. (2020). https data up date covid WHO. WHO. https://www.who.int/emergencies/diseases/novel-coronavirus2019?gclid=Cj0KCQjw8fr7BRDSARIsAK0Qqr5U4TZjykipaMF1vUoJCzIj05 vFtcLMkm0GYe9UM5rfLZxKy8z0X3YaAhPrEALw_wcB

Yuliana. (2020). Wellness and Healthy Magazine, 2(February), 187-192. https://doi.org/10.2307/j.ctvzxxb18.12 